\title{
ON THE READING AND INTERPRETATION OF THE TWO LONGER SIDETIC INSCRIPTIONS S I.2.1 AND S I.2.5
}

\begin{abstract}
In the 1980s I treated the shorter but bilingual Sidetic (= from Side in Pamphylia) inscriptions (3rd to 2 nd century BC). This led to my analysis of the signary as a combination of signs originating from the Phoenician alphabet and Cypro-Minoan syllabary, the latter having their syllabic value reduced to an alphabetic one according to the acrophonic principle. On the basis of the values of the script thus assured the contents of the longer Sidetic inscriptions S I.2.1 and S I.2.5 (both 2nd century BC) can be interpreted. It turns out that we are not dealing with a dedication by a strategos or mere enumerations of personal names, as commonly assumed, but with dedicatory inscriptions showing, next to the personal names, sufficient evidence of vocabulary words and grammatical features. These latter are, as to be expected from a methodological point of view, consistent with the Luwian language. To be more specific, the closest comparative evidence for the Sidetic language is provided by Lycian B, the language of the inhabitants of the region to the west of Side. Accordingly, the Luwian language can be shown to have survived in Side until as late as the 2 nd century BC.
\end{abstract}

\section{INTRODUCTION}

In the 1980s I have discussed in two papers the shorter Sidetic (= from Side in Pamphylia) inscriptions, three of which are bilingual. In the system of numeration by Christian Zinko these entail the bilinguals S I.1.1 (= Artemon bilingual, 2nd century BC), S I.1.2 (= Apollonios bilingual, 3rd century BC), and S I.1.3 (= Euempolos bilingual, late 4 th to early 3 rd century BC), and the monolingual S I.2.2 (= shorter strategos inscription, 2 nd century BC). ${ }^{1}$

The first paper focussed on the signary and the origins of the individual signs. It could be established that in the main the origins are twofold: some signs originate from the Phoenician alphabet (Fig. 1), whereas others could rather be traced back to the Cypro-Minoan syllabary (Fig. 2). ${ }^{2}$ In one case, however, that of the sign for the vowel /a/,

${ }^{1}$ Zinko 2016: 372.

${ }^{2}$ Woudhuizen 1984-5a: 116-120, Figs. 5, 6, 9, 10. 
a third origin should be called into play, as it corresponds in form and value to the Luwian hieroglyphic sign * $19 a^{3}{ }^{3}$ As a by-product of this approach, it could be ascertained that the vertical bar is not a sign rendering a phonetic value (presumed to be of sibilant nature), but a punctuation mark paralleled for the Cypro-Minoan syllabary and, as far as alphabetic scripts are concerned, Carian and used alongside the dot placed half-high or high on the line. ${ }^{4}$

However, this analysis of the signary has not been well received by the colleagues, as is evident from the latest overview of the signary by Zinko, showing only the values as proposed by Johannes Nollé, Santiago Pérez Orozco, and Christian and Michaela Zinko in collaboration with Alfredo Rizza. ${ }^{5}$ Accordingly, in this overview there feature in my opinion a substantial number of erroneous values, which in turn result in erroneous interpretations. Thus the identification of a reflex of the Greek titulary expression strategos in S I.2.1 (2nd century BC) and S I.2.2 is entirely unfounded as is the assumption that S I.2.5 (2nd century BC) merely consists of an enumeration of personal names.

And yet, my claim that the Sidetic signary in the main bears the testimony of a bi-partite origin is duly underlined by the analysis of the related Lydian, Carian, and Lycian alphabets, which also show the use of signs originating from the Cypro-Minoan script, with their syllabic values reduced to letters according to the acrophonic principle, alongside signs originating from the Phoenician alphabet. ${ }^{6}$ To this comes that even a Luwian hieroglyphic influence can be traced in the Phrygian and Lydian alphabet in the form of the figure-of-eight sign /f/, originating from Luwian hieroglyphic $* 280 w_{5},{ }^{7}$ which therefore provides the necessary comparative evidence for the Luwian hieroglyphic origin of the Sidetic vowel /a/ as referred to in the above.

In my second paper I treated the Euempolos bilingual (S I.1.3), and in so doing showed that the first entry in the Sidetic version, Enpel, corresponds to the Greek name and hence that the simplified variant form of $/ \mathrm{n} /$ in form of a hook open at the left side indeed expresses a nasal value (cf. Fig. 2). ${ }^{8}$

On the down side, I also made some mistakes. The first two entries of the Artemon bilingual (S I.1.1) read mie AOana "I (am) for

${ }^{3}$ Woudhuizen 1984-5a: 117-118, Fig. 7.

${ }^{4}$ Woudhuizen 1984-5a: 121; on Carian, see Woudhuizen 2018: 10-11 (C.xx 1; C.Ia 3); 14 (C.Ha 1); Woudhuizen 2019a: 6.

${ }^{5}$ Zinko 2016: 361, Abb. 2.

${ }^{6}$ Woudhuizen 1984-5b: 98, Fig. 2 (Lydian); Woudhuizen 2006: 180, Fig. 5 (Lydian); Woudhuizen 2018: 8, Fig. 2 (Carian); cf. Woudhuizen 2006: 179, Fig. 4 and Woudhuizen 2018: 7, note 10 (Lycian, especially the double-axe sign $\tilde{e}$ ultimately originating from Cretan Linear $a$ ).

${ }^{7}$ Woudhuizen 2016: 5-9.

${ }^{8}$ Woudhuizen 1988-9. 
Athena" instead of $† m_{1} i$ A $\theta$ ana. ${ }^{9}$ Accordingly, the pronoun of the first person singular rather corresponds to Greek $\mu \varepsilon$ "me" than Lydian $\tilde{e} m i_{1}$ "me" and Etruscan $m i$ "I, me" (< Luwian hieroglyphic possessive (á)mi"my"), which is not unlikely given the late date of this text. Note, however, that the in this instance wrongly assumed form of the pronoun is indeed attested for the earlier Euempolos bilingual: $m_{l} i t_{l}{ }^{\bullet}$ "has erected me" (with $t_{l} \bullet$ as a short hand for $t_{1}$ uwete in like manner as $t_{l} u w[$ ete] in the Apollonios bilingual S I.1.2). Secondly, at second thought I think it is unlikely that the signs for /a/ and /š/, in contrast to the one for $/ \dot{s} /$, also occur in mirrored position in the legends on the coins (S III, 5th to 4th century BC). ${ }^{10}$ Accordingly, these legends do not read $\dagger$ Śibušaši $i{ }^{11}$ but Sibuašš $i$, which however does not affect the assumed correspondence of the final part of the sequence to the Luwian adjectival suffix -assi- and hence the translation as: "of Side". Note that coin legends are generally conducted in the genitive, though, it must be admitted, rather in the plural than the singular, cf. Greek $\Sigma_{1}$ $\delta \eta \tau \omega v$ "of the Sidetians" and Lycian Pttaraze "of the Patarians".

As far as the transliteration of the longer texts S I.2.1 and S I.2.5 is concerned, it deserves our attention that in connection with the sign originating from Cypro-Minoan $w a$ I do not use /v/ as indicated in Figs. 2-3, but, in conformity with Lycian practice, /w/.

Of relevance to the transliteration of S I.2.5 is the identification of the newly attested sign no. 24 in Zinko's list as /b/, here rendered as $b_{1}$ in contradistinction from the sign originating from Cypro-Minoan po, our $b .{ }^{12}$ This serves elucidatory purposes in connection with the entry $u b_{1} a t_{1}$ in the sense that it allows us to bring about a connection with Luwian upa- "to found". ${ }^{13}$ This sign is of Phoenician origin as it corresponds to the vertical mem , the development of the sound $/ \mathrm{m} /$ to $/ \mathrm{b} /$ also being attested for the Iberian script. The use of vertical mem indicates that the Sidetic script is typologically of a very ancient nature as the development to horizontal $m \bar{e} m$, typical of inter alia the Phrygian and Greek alphabets, took place at about the middle of the 8th century BC and hence the transmission from Phoenician in the Sidetic case needs to be dated, just like it is the case with the Southwest Iberian script, to the early 8 th or even 9 th century BC. ${ }^{14}$ Also attested for the first time in S I.2.5 is sign no. 20 in Zinko's list in the form of a cross, which is rightly suggested to render the value $/ \chi /$. This sign

\footnotetext{
${ }^{9}$ Woudhuizen 1984-5a: 121-122; cf. Nollé 2001: 631, who reads the name of Athena as Aөono.

${ }^{10}$ The asterisk in Figs. 1 and 3 in these instances should be deleted.

${ }^{11}$ Woudhuizen 1984-5: 123-124.

${ }^{12}$ Zinko 2016: 361, Abb. 2.

${ }^{13}$ Cf. Pérez Orozco 2007: 128; Zinko 2016: 369 with reference to Melchert's suggestion to connect it with the derivative Luwian upati- "landgrant".

${ }^{14}$ Woudhuizen 2006: 175 (I mistakenly wrote †horizontally instead of vertically here); 176, Fig. 2.
} 
originates from the Greek alphabet, for which the use of a simplified form of sibilant no. 15 for $/ \chi /$ is typical. Furthermore, the sign no. 26 in Zinko's list is in my opinion rightly taken by him for a sibilant, though I would add that we are dealing here with a variant of the Sidetic sampi (ultimately originating from the Cypro-Minoan syllabary) and that the sign therefore more likely renders /ss/ (see Figs. 2-3) than Zinko's $/ \mathrm{z} /{ }^{15}$

Finally, it may be observed here that the Sidetic sign for /e/ in the form of a cross with stroke added to the upper left side likely originates from the Cypro-Minoan syllabary in which the vowel/e/ is likewise expressed by a sign in the form of a cross with strokes added to it. $^{16}$

\section{THE LONGER INSCRIPTION S I.2.1}

The longer inscription S I.2.1 appears to be completely preserved. It has been edited most recently by Nollé, whose drawing is reproduced here as our Fig. 4; for a photograph, see Günter Neumann's introduction to the topic. ${ }^{17}$ Nolle doubts the dating of the text to the 2nd century BC because it is not aligned with a Greek text. Yet, it must be dated to the same period as the related shorter text S I.2.2, which is also assigned to the 2 nd century BC. In this latter text, namely, we come across the personal name Trataśo "Tratasos" (N(m/f) sg.), on the basis of which occurrence we can reconstruct the damaged part of line 1 as Trataśewa, the G sg. in -wa (cf. Poloniwa "of Apollonios" in S I.1.2). Moreover, in the latter text further occurs the personal name $\Theta_{1}$ anm $_{1}$ or "Athenodoros", which is also present in S I.2.5. In S I.2.5, finally, there is also mention of Artmon "Artemon" and Eanpiw "Athenippios (G. sg.)", which both occur as son and father in S I.1.1, dated to the 2nd century BC. Mutatis mutandi, the longer inscription S I.2.1 should be assigned to the 2nd century BC as well.

The inscription is reported to have been found in association with reliefs of weapons, dedicated after the successful defence of Side against an attack by Pergamon after the peace of Apameia of 188 BC. ${ }^{18}$ Whatever the extent of the latter observation, it seems likely that the longer inscription S I.2.1 and the associated shorter inscription S I.2.2 are themselves temple dedications or associated with such dedications.

In the longer text under discussion the reference to the MN Tratasos in line 1 is followed by the sequence /i/Trataśeš "on behalf of

${ }^{15}$ Zinko 2016: 361, Abb. 2.

${ }^{16}$ Woudhuizen 2017: 38, Fig. 7 (Cypriot Syllabary); cf. 71, Fig. 11 (Cypro-Minoan or Linear C).

${ }^{17}$ Nollé 2001: 634-637; Neumann 1968: Taf. I, 1-2.

${ }^{18}$ Nollé 2001: 635; cf. Nollé 1993: 63-68. 
this Tratasos" in line 2, where it occurs in the dative singular in $-\check{s}$ (corresponding to the Etruscan D-G sg. in $-s)^{19}$ and happens to be preceded by the element $/ \mathrm{i} /$, separated by two instances of the punctuation mark. Clearly, we have an instance here of the Luwian hieroglyphic demonstrative pronoun $i$ - "this", ${ }^{20}$ so "this Tratasos", where the demonstrative refers back to the person mentioned in line 1. A similar conclusion applies to the mention of this same demonstrative pronoun also before the MN Tratasos in the shorter inscription S I.2.2. Here it is clear that /i/Trataśo "this Tratasos $(\mathrm{N}(\mathrm{m} / \mathrm{f}) \mathrm{sg}$.)" (cf. the endingless $\mathrm{N}(\mathrm{m} / \mathrm{f}) \mathrm{sg}$. in Lycian) ${ }^{21}$ refers to a person whose identity is clear from the associated dedications and no doubt the associated longer text. Note that the MN Tratasos is of similar type as Lycian Trijẽtezi-, ${ }^{22}$ which is based on Proto-Indo-European (= PIE) *tri-to- "third" ${ }^{23}$ and may therefore safely be assumed to show a reflex of Luwian hieroglyphic tar- "three". 24

The suggestion that the longer text S I.2.1 is associated with dedications in a temple further gains weight from the observation that in the text reference is made to maśaraśe in line 1 and mešar 1 a in line 2. These entries are intrinsically linked up with maśara in the bilingual inscription S I.1.2, which corresponds to Greek $\theta \varepsilon 01 \varsigma \pi \alpha \sigma \mathrm{lv}$ "to all gods". The first part of this word recalls the short hand of Luwian hieroglyphic masana- "god", masa- ${ }^{25}$ which in turn corresponds to Lycian B masa- "god" ${ }^{26}$ Clearly, we have a reference here to a god or gods. In the present context, the god in question is specified as ana- "mother" (see discussion of anaśe below), corresponding to Luwian hieroglyphic $a n a^{27}$ and Lycian ene- of the same meaning. ${ }^{28}$ Against the backdrop of cuneiform Luwian anniš maššsanašššš and Lycian ẽni mahana$h i$ "the Mother of the (two) gods", it is clear that with this kinship term reference is made to the divine Mother, in the Lycian context Leto, the mother of Artemis and Apollo. ${ }^{29}$ In this light, I am inclined to analyze Sidetic maśara as a compound of maśa- with the enclitic element - $r a$ originating from Luwian $u r a-$ "great" ${ }^{30}$ in short a reference to the Great Goddess. On account of its correspondence to Greek $\theta \varepsilon o 1 \varsigma$

${ }^{19}$ Woudhuizen 2008: 394.

${ }^{20}$ Woudhuizen 2011: 140; 337.

${ }^{21}$ Melchert 2004: x.

${ }^{22}$ Melchert 2004: 105.

${ }^{23}$ Mallory \& Adams 2007: 311.

${ }^{24}$ Woudhuizen 2011: 359.

${ }^{25}$ Woudhuizen 1984-5a: 122-3 with note 12; Woudhuizen 2011: 252, Karatepe $\S 51$.

${ }^{26}$ Melchert 2004: 120.

${ }^{27}$ Woudhuizen 2011: 321.

${ }^{28}$ Melchert 2004: 20.

${ }^{29}$ Laroche 1979: 85.

${ }^{30}$ Woudhuizen 2011: 145; 366-367; for the enclitic use or ura-, cf. Linear D tablet inv. 1687, line 13 purar-ura "great king", line 15 nukar-ura "great enemy", line 2 akara-ra "great headman", and line 17 zusi-ra "great army camp", see Woudhuizen 2017: 133-150. 
$\pi \alpha \sigma \mathrm{v}$, maśara in S I.1.2 clearly renders the D sg. in - $a$, corresponding to Lycian $-a$ (a-stems) for the same function. ${ }^{31}$ The same no doubt applies to mešar ${ }_{1} a$ in line 2 of the present text. As opposed to this, maśaraśe in line 1 shows the adjectival suffix $-s$ - and the ending of the $\mathrm{G}$ pl. in -e, corresponding to Lycian - $-\tilde{e}$ as in Pttaraze "of the Patarians" (see further below). ${ }^{32}$

Finally, it deserves our attention that at the end of line 3 we can distinguish the sequence anatemata which also features at the end of the shorter S I.2.2. This is nothing but Greek $\alpha v \alpha \theta \eta \mu \alpha \tau \alpha$ "votive offerings" in Sidetic rendering. Clearly, therefore, both inscriptions were associated with temple dedications. Note that anatemata renders the $\mathrm{N}-\mathrm{A}(\mathrm{n}) \mathrm{pl}$. in $-a$, corresponding to Luwian, Lycian, and Lydian $-a$ for the same function, ${ }^{33}$ which definitely rules out the interpretation of the following punctuation mark in form of vertical line as a phonetic sign rendering a sibilant value.

Our transliteration and interpretation, further elaborated in the commentary below with respects to the elements which thus far have not received proper treatment, of the entire text runs as follows:

1. wešaśe anaśe-i/Trataśewa//awešaśe maśaraśe

2. $m_{1} \operatorname{arr}_{l} e \check{s} m_{1}$ i une/i-wa/mešar ${ }_{l} a /$ i/Trataśešs/ar ${ }_{1} \mathrm{O}$

3. peniwa śeš nenarśar ${ }_{1} a /$ aar $_{1}$ o/ $\operatorname{am}_{1}($ a) anaOematal
"Of the goods of the Mother here, of Tratasos, i.e. of the goods of the Great Goddess

for my wife according to the laws, on behalf of this Great Goddess, on behalf of this Tratasos, the citizen,

I pay to his sister, the citizen, my votive offerings."

Table I: The Sidetic inscription S I.2.1

in transliteration and translation.

\section{Comments}

In outline, the inscription runs as follows: it starts with a sequence conducted in the genitive, of which the vocabulary word wešais most prominent as it features twice. This corresponds to Lycian B wese- "good", the noun. ${ }^{34}$ Like the entries anaśe and maśaraśe, this noun appears in adjectival derivative in $-s$ - and marked by the $\mathrm{G}$ pl. in $-e$, corresponding to Lycian $-\tilde{e}$ for the same function. Of these goods, which are dedications to ana- the Mother or maśara- the Great Goddess

${ }^{31}$ Houwink ten Cate 1961: 53.

32 Melchert 2004: x.

${ }^{33}$ Woudhuizen 2011: 432; note that this is a common Indo-European feature, cf. Szemerényi 1970: 171.

${ }^{34}$ Melchert 2004: 134. 
by Tratasos, a part is reserved for the wife of the principal of the text ( $m_{1} i$ une "for my wife") according to the laws $\left(m_{1} a{ }_{1} e_{l} e s\right)$. From this part of the goods reserved for his wife, then, the principal pays (peniwa "I pay") his votive offerings $\left(\operatorname{am}_{1}(a)\right.$ anatemata "my votive offerings") to the sister of the ultimate dedicator (śeš nenarśar ${ }_{1} a$ "his sister"), Tratasos. He does so explicitly on behalf of the aforesaid ( $i$ - "this") Great Goddess and the aforesaid ( $i$ - "this") Tratasos, the primary owners of the goods.

We have here an example of complicated ownership of votive offerings, which is specified in detail, involving (1) the goddess, (2) Tratasos, (3) the wife of the principal of the text, and (4) the latter himself. Note that the principal of the text is not mentioned by his name, so his identity must have been clear from the context of the inscription.

To underline the validity of this interpretation, the following elements may be further specified as follows:

\section{Line 1}

$-i$ : Loc. sg. of the enclitic pronoun of the 3rd person, corresponding to Lycian $-i$ of the same function. ${ }^{35}$

$a-:$ introductory particle, corresponding to cuneiform Luwian $a$ and Luwian hieroglyphic $\grave{a}-.{ }^{36}$

\section{Line 2}

$m_{1} \operatorname{arr}_{1} e \check{s}: \mathrm{A}(\mathrm{m} / \mathrm{f}) \mathrm{pl}$. in -ěs, corresponding to Lycian -es (estems) for the same function, ${ }^{37}$ of the noun $m_{1} \operatorname{arr}_{1}(e)$ - "law", corresponding to Lycian mara- or mere- of the same meaning. ${ }^{38}$

$m_{1} i$ : D sg. in $-i$ of possessive pronoun of the 1 st pers. sg. $m_{1} i-$, corresponding to Luwian hieroglyphic $(\dot{a}) m i$ for the same function. ${ }^{39}$

une: $\mathrm{D}$ sg. in $-e$, corresponding to the Etruscan D sg. in $-e,{ }^{40}$ of the noun un(i)- "wife", corresponding to Luwian wana(tti)- "woman, wife" 41 and Etruscan uni- "lady". 42

$i$ : D sg. of the demonstrative pronoun $i$ - "this", corresponding to Luwian hieroglyphic $i$ for the same function. ${ }^{43}$ This form occurs twice in this line.

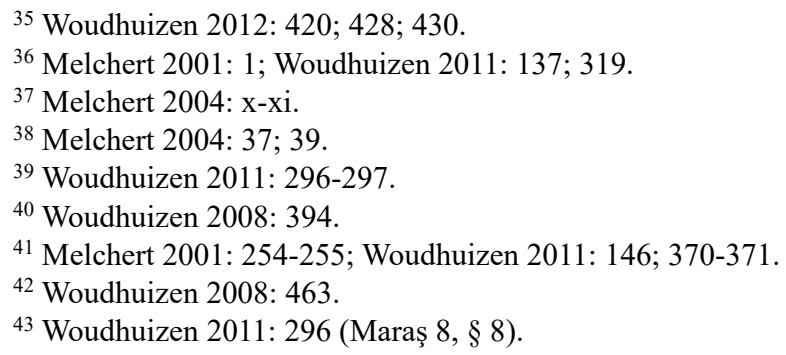


-wa: introductory particle, corresponding to Luwian $-w a{ }^{44}$

$a r_{l} o$ : D sg. in $-o$, corresponding to the Etruscan D sg. in $-u,{ }^{45}$ of the noun $\operatorname{ar}_{1}(o)$ - "citizen", related to Lycian arus- "citizenry" ${ }^{46}$ This form also occurs in writing variant $\operatorname{aar}_{l} o$ in line 3.

\section{Line 3}

peniwa: 1st pers. sg. of the present/future tense in -wa, corresponding to Luwian hieroglyphic - wa for the same function, ${ }^{47}$ of the verb peni- "to pay", corresponding to Lycian B pẽniu $u^{48}$ of which the meaning can be ascertained owing to the fact that the root of the verb corresponds to Etruscan pen $(\theta)$ - "to pay". 49

śeš: D sg. in $-\check{s}$, corresponding to the Etruscan pronominal D-G sg. in $-s,{ }^{50}$ of the possessive pronoun of the 3 rd pers. se- "his". This possessive pronoun goes unparalleled among the representatives of the Luwian language group, but a relationship to the PIE anaphoric *se of which the Latin reflexive pronoun $s \bar{e}$ "him-, her-, itself" bears the testimony, more in specific originating from PIE $*$ séwe, ${ }^{51}$ might be suggested-especially so as the Latin possessive pronoun suus "his" also is derived from this latter PIE root. ${ }^{52}$

nenarśar ${ }_{1} a$ : D sg. in - $a$ of the noun nenarśar ${ }_{1}(a)$ - "sister", related to cuneiform Luwian nānašri(ya)- "of a sister".

$a m_{1}(a): \mathrm{N}-\mathrm{A}(\mathrm{n}) \mathrm{pl}$. in $-(a)$ of the possessive pronoun of the $1 \mathrm{st}$ pers. sg. $a m_{1}(i)-$ "my", corresponding to Luwian hieroglyphic áma for the same function. ${ }^{54}$

\section{THE LONGER INSCRIPTION S I.2.5}

The longer inscription S I.2.5 was discovered by Nollé in the museum of Side in 1995 and subsequently published in his book of $2001 .^{55}$ However, an improved drawing was produced by Michaela Zinko and published by Christian Zinko in his paper of 2016 as Abb. 3 (together with a photograph, his Abb. 1). ${ }^{56}$ This latter drawing is

\footnotetext{
${ }^{44}$ Melchert 2001: 249; Woudhuizen 2011: 146; 369.

${ }^{45}$ Woudhuizen 2008: 394.

${ }^{46}$ Melchert 2004: 5.

${ }^{47}$ Woudhuizen 2011: 314.

${ }^{48}$ Melchert 2004: 124.

${ }^{49}$ Woudhuizen 2008: 458.

${ }^{50}$ Woudhuizen 2008: 394.

${ }^{51}$ Mallory \& Adams 2007: 416-417.

${ }^{52}$ Szemerényi 1970: 203-204.

${ }^{53}$ Melchert 2001: 154.

${ }^{54}$ Woudhuizen 2011: 300.

${ }^{55}$ Nollé 2001: 642-644.

${ }^{56}$ Zinko 2016: 362, Abb. 3 (drawing); 360, Abb. 1 (photograph).
} 
reproduced here as our Fig. 5. The text is incompletely preserved and there is certainly one line on top and one line following the well-preserved six lines.

According to Zinko's analysis, this text consists entirely of an enumeration of personal names. As we will see, this is a testamentum paupertatis, as the text bears ample testimony, alongside a number of personal names, of vocabulary words and grammatical features.

Among the personal names rightly identified as such by Zinko feature Artmon "Artemon" (line 2) and @anpiw "Athenippios (G. sg.)" (line 6) ${ }^{57}$ As both these names (as son and father) are paralleled for $\mathrm{S}$ I.1.1, which is dated to the 2nd century BC, it likely follows (although this is not made explicit by Zinko) that S I.2.5 also dates to the 2nd century BC. Other personal names are $\Theta a n m_{1}$ or "Athenodoros" in lines 3 and $5(2 x)$, which is paralleled for S I.2.2, also assigned to the 2nd century BC, and Talamoniwa "Telamon (G sg.)" in line 6, attested here for the first time. ${ }^{58}$

A first hint at the presence of other elements than personal names is provided by the entry $u b_{1} a t_{1}$, as we have seen rightly read as such by Zinko. Instead of an onomastic element, we are dealing here with a verbal form, the root of which is related to Luwian upa- and Lycian ube- "to found". ${ }^{59}$ This verbal form, then, renders the 3rd pers. $\mathrm{sg}$. of the present/future in $-t_{l}$, corresponding to Luwian $-t i$, Lycian $-d / t i$, and Lydian $-d / t$ for the same function. ${ }^{60}$ From the context, it seems likely that we are dealing here with a praesens historicum and that this verbal form actually renders the past tense.

At any rate, the things which the dedicator "has founded" are

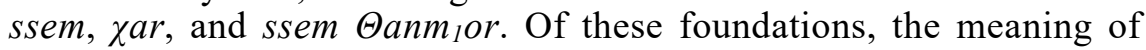
ssem can be elucidated thanks to its relationship in form to Carian sșam "memorial", a reflex of Greek $\sigma \tilde{\eta} \mu \alpha .{ }^{61}$ Accordingly, the ssem $\Theta a n m_{1}$ or is distinct from the memorial as such and denotes "the memorial (for) Athenodoros". Finally, $\chi a r$ is an abbreviation of Greek $\chi \alpha-$

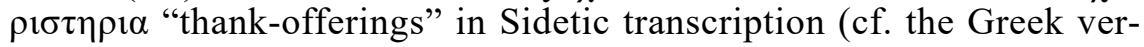
sion of the bilingual S I.1.1), thus the dedicator has also founded thank-offerings.

The word ssem "memorial" also features twice in line 2. First, it is followed by $i$, which likely renders the $\mathrm{N}-\mathrm{A}(\mathrm{n}) \mathrm{sg}$. in $-i$ (cf. Luwian hieroglyphic $-\bar{l}$ and Lydian $\left.-i_{1}\right)^{62}$ of the demonstrative pronoun $i$ "this", postpositioned here. Alternatively, we could be dealing here with the Loc. sg. $-i$ of the enclitic pronoun of the 3rd pers. This sequence is

${ }^{57}$ Zinko 2016: 365; 369; 371.

${ }^{58}$ Zinko 2016: 367-368; 371.

${ }^{59}$ Woudhuizen 2011: 366; 430. Cf. Melchert 2001: 242 and Melchert 2004: 75, who wrongly suggests the meaning "to grant".

${ }^{60}$ Woudhuizen 2011: 314; Melchert 2004: xii; Woudhuizen 2019b: 179.

${ }^{61}$ Woudhuizen 2018: 15-16 (bilingual text G 1 from Athens); also Luwian hieroglyphic sà-ma- "memorial", see Woudhuizen 2011: 353.

${ }^{62}$ Woudhuizen 2011: 295; 314; Woudhuizen 2019b: 179. 
followed by to, which corresponds to the $\mathrm{D}$ of the Luwian hieroglyphic enclitic pronoun of the 3rd pers., - $t u$ "for him". ${ }^{63}$ Next, follows the combination ssem Artmon, according to which the memorial with which the inscription was associated is specified as being for Artemon.

The next word of critical importance for our understanding of the text is powaš, which occurs in lines 3,5, and 7 (2x). The meaning of this word can be retrieved from oblivion owing to its correspondence to Luwian hieroglyphic $p u$ - and Lycian $p(p) u w e-$ "to write (by testament), to inherit" ${ }^{64}$ In the present case, we are dealing with an adjectival derivative in $-\check{s}-$, rendering the meaning "inheritance". If we realize that śari is a reflex of the Luwian hieroglyphic pre- or postposition sara "up, above" (= cuneiform Luwian šarri, Lycian hri, Lydian sar), ${ }^{65}$ it follows that in line 3 it is stated that powaš @anm ${ }_{1}$ or śari "the inheritance (of) Athenodoros (is) on top". Next, it now becomes clear that in lines 4-5 it is stated that the dedicator $u b_{1} a t_{1}$ ssem $\Theta a n-$ $m_{1}$ or powaš/@anm 1 or "has founded the memorial (for) Athenodoros (from) the inheritance (of) Athenodoros".

Finally, the entry piś which follows this latter statement likely renders the $\mathrm{N}(\mathrm{m} / \mathrm{f}$ ) sg. in $-s$ (cf. Luwian hieroglyphic $-s a$ and Lydian $-s$ or $\left.-s^{6}\right)^{66}$ of the relative pronoun $p i-$ "who, what", corresponding to Lydian $p i$ - of the same meaning. ${ }^{67}$ If this is correct, it may reasonably be assumed that this form of the relative pronoun introduces the protasis of the damnation formula which warns a possible desecrator of the monument for divine retribution. This latter inference receives further emphasis from the fact that the next entry, $e t_{1} o b_{1} e_{l} \check{s}$, confronts us with yet another verbal form, this time one showing a reflex of Luwian hieroglyphic tupa- "to strike, hit", of which the related forms in Lycian $(t u b(e) i-)$ and Lydian $\left(v t_{1} b a-\right)$ feature prominently in damnation formulas (mostly in the apodosis). ${ }^{68}$ As it seems, we are dealing here with a verbal form characterized by the augment, which is foreign to Luwian but typical for Phrygian (edaes), and Greek ( $\check{\varepsilon} \lambda v \varepsilon$, $\check{\varepsilon} \lambda \nu \sigma \varepsilon)$. Among the Luwian dialects, it is paralleled as a Phrygian or Greek loan ele-

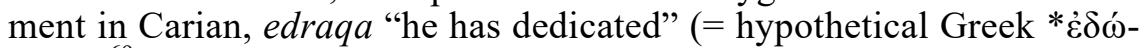
$\rho \eta \kappa \varepsilon) .{ }^{69}$ Note that the sign in form of an /a/ with an extra stroke of this verbal form has been transliterated here as $e_{1}$. The entry remar which follows this verbal form I analyze as a composite form, consisting of

\footnotetext{
${ }^{63}$ Woudhuizen 2011: 132; 313.

${ }^{64}$ Woudhuizen 2011: 351; 428; Melchert 2004: 54.

${ }^{65}$ Woudhuizen 2011: 142; 353; 428. Cf. Melchert 2004: 24.

${ }^{66}$ Woudhuizen 2011: 292; 314; Woudhuizen 2019b: 179.

${ }^{67}$ Woudhuizen 1984-5b: 102. Note that Lycian has $t i$ - and that, as the Luwian form is $k u i$ - or $k w a$-, both these forms are the result of a labiovelar development $* k^{w}>p, t$.

${ }^{68}$ Houwink ten Cate 1961: 95, TL 88; Woudhuizen 2011: 429; Woudhuizen 1984-5b:
} 99-100.

${ }^{69}$ Woudhuizen 2019a: 8-9. 
the element re-, corresponding to Lycian eri ( $<$ Luwian arha "de-, away"), ${ }^{70}$ and mar-, corresponding to Lycian mara- or mere- "law", rendering the meaning "unlawfully". The apodosis of the damnation formula should be reconstructed for line 8 which unfortunately has been damaged beyond the means of repair.

In sum, this leads us to the following transliteration and interpretation of the text in its entirety:

\section{1. $] r[$ \\ 2. ssem-i/to/ssem/Artmon/ \\ 3. powaš @anm \\ 4. $u b_{1} a t_{1} \operatorname{ssem} u b_{1} a t_{1} \chi a r / u b_{1} a t_{1}$ ssem/}

5. anm $_{1}$ or powaš/@anm ${ }_{1}$ or/

6. $t_{1} o b_{1} e_{I} \check{s}$ remar @anpiw/

Talamoniwa

7. [p]owaš powaš / @anm ${ }_{1}$ or/śari/

8. [ ss]em/
[ ] ]

"This memorial for him: the memorial (for) Artemon."

"The inheritance (of) Athenodoros (is) on top."

"He has founded the memorial, he has founded the thank-offerings, he has founded the memorial (for) Athenodoros (from) the inheritance (of) Athenodoros"

piś/e "Who(ever) unlawfully has brought damage to the inheritance of Athenippios (and) Telamon (or) the inheritance (of) Athenodoros on top," "[
] the memorial."

Table II. The Sidetic inscription S I.2.5

in transliteration and translation.

\section{CONCLUSIONS AND GRAMMATICAL SKETCH OF THE SIDETIC LANGUAGE}

In the discussion of the longer Sidetic texts S I.2.1 and S I.2.5, both dating to the 2 nd century $\mathrm{BC}$, we have seen that there is, apart from the mention of personal names, ample evidence of the Sidetic language, in the form of vocabulary words and grammatical features. Of prime importance is the identification of the vertical bar as a punctuation mark instead of a phonetic sign. It helps us to distinguish the individual words and elements. Among these latter features prominently, especially so in text S I.2.1, the demonstrative pronoun $i$ - "this". In this way, Sidetic provides independent evidence for the existence of this demonstrative in the Luwian language. Elsewhere, I have shown that the new reading of Luwian hieroglyphic is basically flawed and that the adjusted old reading as proposed by me is the only valid one. ${ }^{71}$

\footnotetext{
${ }^{70}$ Woudhuizen 2011: 424.

${ }^{71}$ Woudhuizen 2019c: Notes 3 and 4.
} 
According to this latter reading, then, the Luwian hieroglyphic demonstrative pronoun must be rendered as $i$ - or $\bar{l}$, and not as $\dagger z i$ - or $\dagger z a-$. From an Indo-European point of view, one is reminded in this connection of Latin is, ea, id. However, this pronoun is also independently attested for the so-called Songs of Istanuwa in cuneiform Luwian in the form of iya "these (N-A(n) pl.)". ${ }^{72}$

But also the remaining linguistic data are, with the noted exceptions of the possessive pronoun se- "his", the G sg. ending in -w(a), and a few Greek loans, consistent with what we know of the Luwian language as represented by cuneiform Luwian, Luwian hieroglyphic, Lycian, Carian, and Lydian. What is even more, among these dialects the Sidetic language shows the closest affinity to Lycian B as is to be expected from a general perspective, this being the language of the closest neighbors of the inhabitants of Side and by and large from about the same chronological horizon as the Sidetic texts. It may safely be concluded, therefore, that in the form of Sidetic the Luwian language survived well into the 2nd century BC.

Finally, it deserves our attention that not only the Sidetic script shows affinity with the Etruscan alphabet, ${ }^{73}$ but also the Sidetic language shows features most intimately paralleled for the Etruscan language. This observation coincides with my identification of Etruscan as a colonial Luwian language, introduced into the regions of Campania and Tuscany by population groups originating from the entire west and southwest coast of Anatolia during the late 8th and/or early 7th century BC.

For the sake of convenience, I herewith present an overview of the grammatical features as rendered in Table III below.

$$
\text { noun sg. } \begin{aligned}
& \text { plonoun noun } \\
&
\end{aligned}
$$

$\begin{array}{lcccc}\mathrm{N}(\mathrm{m} / \mathrm{f}) & - & -\dot{s} & & -e \check{s} \\ \mathrm{~A}(\mathrm{~m} / \mathrm{f}) & & & -a & -a \\ \mathrm{~N}-\mathrm{A}(\mathrm{n}) & -a,-e,-o & -i & & \\ \mathrm{D} & -\check{s} & -\check{s} & & \\ \mathrm{D}-\mathrm{G} & -w(a) & & -e & \end{array}$

Abl.-Instr.

Loc.

verb

1st pers. sg. pres./fut. act. $\quad-w a$

72 Woudhuizen 2019c: 253 (with ref.).

${ }^{73}$ Woudhuizen 1984-5a: 121, Fig. 11. 
3rd pers. sg. pres./fut. act. $\quad-t_{l}$

3rd pers. sg. past tense act. $-\check{s}$

Table III. Overview of the evidence of (pro)nominal declension and verbal conjugation.

\section{APPENDIX}

As rightly observed by Christian Zinko, the verb $u b_{1} a t_{1}$ "he has founded" of S I.2.5 also occurs in the legend of a bronze voting tablet, S II.1.1. ${ }^{74}$

This object has not been found in its archaeological context, but surfaced on the market. It has first been published with a photograph by Claude Brixhe in $1969 .{ }^{75}$ Subsequently, it was included in Nollé's overview of Sidetic inscriptions of 2001 as his S 5, of which the drawing is reproduced here as our Fig. $6 .{ }^{76}$ Note that the sign for $b_{1}$, originating, as we have seen, from the Phoenician vertical $m \bar{e} m$, is not yet distinguished in this drawing from the simplified variant of $n$ originating from Cyprian Syllabic $n u$.

The inscription on the bronze voting tablet is dated to the late 3 rd or early 2 nd century BC. This dating coincides with the mention of the MN Artmon "Artemon" in line 1, which also features in S I.1.1 of the 2nd century BC and S I.2.5, presumably, as we have seen, from the same date. The original text of this voting tablet is reported to have been erased, so the present text is a secondary one, not necessarily linked up with the original function of the tablet in the political context for voting.

To the right of the legend is the depiction of a pomegranate, the symbol of the city of Side, whereas to the left is written a large alpha, no doubt the abbreviation of the MN Artemon. tation:

In sum, the text reads as follows in transliteration and interpre-

1. Artmon ublat 1 šoro/

2. $u b_{1} a t_{1}$ šoro/
"Artemon has founded the sarcophagus." "He has founded the sarcophagus."

Table IV. The Sidetic inscription S II.1.1 in transliteration and translation.

The crux for the interpretation of the legend is formed by the enigmatic entry šoro following the verb $u b_{1} a t_{1}$ "he has founded". In the discussion of S I.2.5 above we have seen that here this verb is fol-

${ }^{74}$ Zinko 2016: 369-370.

${ }^{75}$ Brixhe 1969, esp. Planche I, 3-4.

${ }^{76}$ Nollé 2001: 639-640. 
lowed by ssem "memorial" (2x) and $\chi$ ar, the abbreviation of Greek $\chi \alpha-$

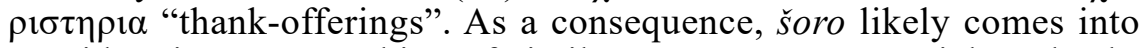
consideration as something of similar nature as a memorial or thankofferings.

Now, from an etymological point of view šoro bears a striking resemblance to Phrygian sorou (D sg.), which in a bilingual inscription from Aşaği Piribeyli (= Lower Piribeyli) near Afyon, catalogued by

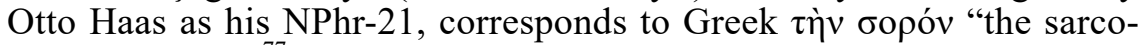
phagus (A sg.)" ${ }^{77}$ The same form is also attested for another New Phrygian (2nd to 3rd century AD) inscription from Aşağ1 Piribeyli published by Brixhe and Thomas Drew-Bear in 1997 (their number VII). ${ }^{78}$ What primarily concerns us here, however, is that in form soroi (D sg.) this loan from Greek oopó $\varsigma$ "sarcophagus" already occurs in a Phrygian inscription in the Greek alphabet from Dokimeion (W-11, line 3) dated to the late 4th or early 3rd century BC, published by Brixhe in $2004{ }^{79}$ Accordingly, the loan from Greek in this particular case already took place in the Anatolian context during the Hellenistic period, prior to the date of our Sidetic inscription S II.1.1.

It lies at hand, therefore, to conclude that the bronze voting tablet under discussion was secondarily used to commemorate the foundation by Artemon of a sarcophagus and as such was placed in direct association with this sarcophagus, presumably located in the temple or some other public place.

\section{BIBLIOGRAPHY}

Brixhe, Claude. 1969. Un nouveau document épichorique de Sidé. Kadmos 8. Pp. 143151.

—. 2004. Corpus des inscriptions paléo-phrygiennes, Supplément II. Kadmos 41. Pp. 1130.

Brixhe, Claude, \& Drew-Bear, Thomas. 1997. Huit inscriptions néo-phrygiennes. In: Gusmani, Roberto, Salvini, Mirjo, \& Vannicelli, Pietro, (eds.), Frigi e Frigio, Atti del $1^{0}$ Simposio Internazionale, Roma, 16-17 ottobre 1995. Pp. 71-114. Roma: Consiglio Nazionale delle Ricerche.

Diakonoff, I.M., \& Neroznak, V.P. 1985. Phrygian. Delmar, New York: Caravan Books.

Haas, Otto. 1966. Die phrygischen Sprachdenkmäler. Linguistique Balkanique 10. Sofia: Academie Bulgare des Sciences.

${ }^{77}$ Haas 1966: 79; 117; cf. Diakonoff \& Neroznak 1985: 83; 134 and Woudhuizen 2008-9: 189; 205.

${ }^{78}$ Brixhe \& Drew-Bear 1997: 102-104.

${ }^{79}$ Brixhe 2004: 7-26, esp. p. 18; Brixhe \& Drew-Bear 1997: 103; cf. Lubotsky 2017: 427 (line 3). 
Houwink ten Cate, Philo H.J. 1961. The Luwian Population Groups of Lycia and Cilicia Aspera during the Hellenistic Period. Leiden: E.J. Brill (dissertation).

Laroche, Emmanuel. 1979. La stèle trilingue du Létôon: version lycienne. In: Metzger, Henri, (éd.), Fouilles de Xanthos VI. Pp. 49-127. Paris: Librairie C. Klincksieck.

Lubotsky, Alexander. 2017. The Phrygian inscription from Dokimeion and its meter. In: Hajnal, Ivo, Kölligan, Daniel, \& Zipser, Katharina, (Hrg.), Miscellanea Indogermanica, Festschrift für José Luis García Ramón zum 65. Geburtstag. Pp. 427-431. Innsbruck: Innsbrucker Beiträge zur Sprachwissenschaft.

Mallory, James P., \& Adams, Douglas Q. 2007. The Oxford Introduction to Proto-IndoEuropean and the Proto-Indo-European World. Oxford: Oxford University Press (reprint of 2006 edition).

Melchert, H. Craig. 2001. Cuneiform Luvian Lexicon. Lexica Anatolica, Volume 2. Chapel Hill, N.C. (online version of 1993 edition).

—. 2004. A Dictionary of the Lycian Language. Ann Arbor-New York: Beech Stave Press.

Neumann, Günter. 1968. Zur Entzifferung der sidetischen Inschriften. Kadmos 7. pp. 7593.

Nollé, Johannes. 1993. Side im Altertum: Geschichte und Zeugnisse. Band II: Geographie, Geschichte, Testimonia, Griechische und lateinische Inschriften (1-4). Inschriften griechischer Städte aus Kleinasien 43. Bonn: Dr. Rudolf Habelt GmbH.

—. 2001. Side im Altertum, Geschichte und Zeugnisse. Band II: Griechische und lateinische Inschriften (5-16) - Papyri - Inschriften in sidetischer Schrift und Sprache - Ergänzungen und Berichtigungen - Konkordanzen - Epigraphische Indices. Inschriften griechischer Städte aus Kleinasien 44. Bonn: Dr. Rudolf Habelt GmbH.

Pérez Orozco, Santiago. 2007. La lengua Sidética, Ensayo de síntesis. Kadmos 46. Pp. 125-142.

Szemerényi, Oswald. 1970. Einführung in die vergleichende Sprachwissenschaft. Darmstadt: Wissenschaftliche Buchgesellschaft.

Woudhuizen, Fred C. 1984-5a. Origins of the Sidetic Script. Talanta, Proceedings of the Dutch Archaeological and Historical Society 16-17. Pp. 115-127.

—. 1984-5b. Lydian: Separated from Luwian by three signs. Talanta, Proceedings of the Dutch Archaeological and Historical Society 16-17. Pp. 91-103.

—. 1988-9 The Recently Discovered Greek-Sidetic Bilingue from Seleucia. Talanta, Proceedings of the Dutch Archaeological and Historical Society 20-21. Pp. 87-96.

- 2006. The Transmission of the Phoenician Alphabet in the Mediterranean Region. Rivista di Studi Fenici 34, 2 [2009]. Pp. 173-184.

—. 2008. Etruscan as a Colonial Luwian Language. Innsbrucker Beiträge zur Kulturwissenschaft, Sonderheft 128. Innsbruck: Innsbrucker Beiträge zur Kulturwissenschaft.

-. 2008-9. Phrygian \& Greek. Talanta, Proceedings of the Dutch Archaeological and Historical Society 40-41. Pp. 181-215.

—. 2011. Selected Luwian Hieroglyphic Texts: The Extended Version. Innsbrucker Beiträge zur Sprachwissenschaft, Band 141. Innsbruck: Innsbrucker Beiträge zur Sprachwissenschaft.

- 2012. Lycian Forms of the Enclitic Pronoun of the $3^{\text {rd }}$ Person: An Overview of the Relevant Data. Colloquium Anatolicum 11. Pp. 415-436.

—. 2016. The Luwian Hieroglyphic Contribution to the Alphabet. Živa Antika 66. Pp. 514.

- 2017. The Language of Linear C and Linear D from Cyprus. Publications of the Henri Frankfort Foundation 15. Amsterdam: Dutch Archaeological and Historical Society.

—. 2018. Carian: On the Luwian-Greek interface. Živa Antika 68. Pp. 5-24. 
2019a. A Carian inscription from Mylasa. Živa Antika 69. Pp. 5-9.

2019b. The Role of Brotherhoods in West-Luwian Religion (5th to 2nd Century BCE). In: Hutter, Manfred, \& Hutter-Braunsar, Silvia, (Hrg.), Economy of Religions in Anatolia: From the Early Second to the Middle of the First Millennium $\mathrm{BCE}$, Proceedings of an International Conference in Bonn $\left(23^{\text {rd }}\right.$ to $25^{\text {th }}$ May 2018). Alter Orient und Altes Testament, Veröffentlichungen zur Kultur und Geschichte des Alten Orients und des Alten Testaments 467. Pp. 169-180. Münster: Ugarit-Verlag.

—. 2019c. Four Notes on Luwian Hieroglyphic. Ancient West \& East 18. Pp. 245-264.

Zinko, Christian. 2016. Die sidetische Namenliste (S I.2.5). In: Marquardt, Henning, Reichmuth, Silvio, \& García Trabazo, José Virgilio, (Hrg.), Anatolica et Indogermanica, Johannis Tischler septuagenarii dedicata. Innsbrucker Beiträge zur Sprachwissenschaft, Band 155. Pp. 359-374. Innsbruck: Innsbrucker Beiträge zur Sprachwissenschaft.

Zinko, Christian, \& Zinko, Michaele. 2019. Sidetisch - Ein Update zu Schrift und Sprache. In: Kim, Ronald I., Mynářová, Jana \& Pavúk, Peter (eds.), Hrozný and Hittite, The First Hundred Years. Proceedings of the International Conference Held at Charles University, Prague, 11-14 November 2015. Culture and History of the Ancient Near East, Volume 107. Pp. 416-432. Leiden-Boston: Brill.

Zinko, Michaela, Zinko, Christian, \& Rizza, Alfredo. 2016. Bemerkungen zur sidetischen Schrift - Eine aktuelle Bestandaufnahme. In: Cotticelli-Kurras, Paola, \& Rizza, Alfredo, (eds.), Variation within and among Writing Systems, Concepts and Methods in the Analysis of Ancient Written Documents. LautSchriftSprache 1. Pp. 371-384. Wiesbaden: Dr. Ludwig Reichert Verlag.

Origin A: Phoenician Alphabet

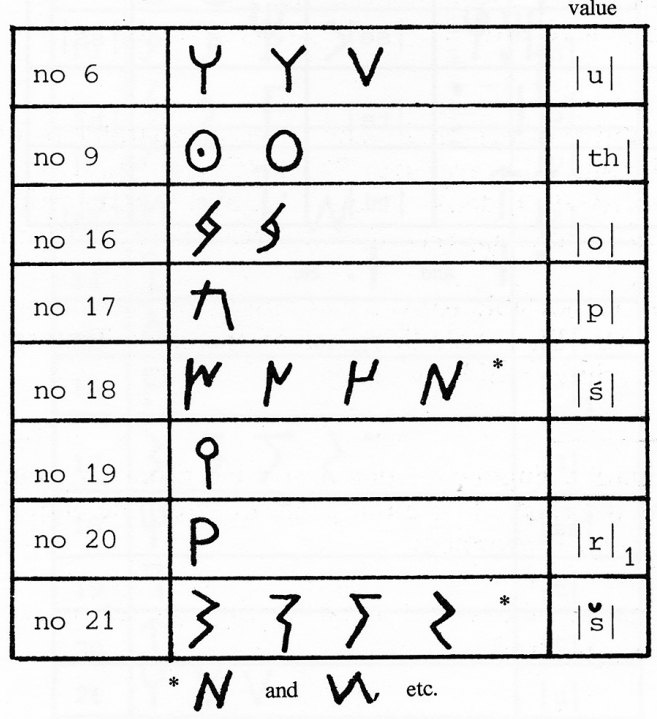

Fig. 1. Signs from the Phoenician alphabet

(Woudhuizen 1984-5a: 125, Fig. 12). 
Origin B: Cypro-Minoan Syllabary

\begin{tabular}{|c|c|c|c|c|}
\hline C.L. & C.S. & value & Sidetic & value \\
\hline & & $|\mathrm{po}|$ & $\sum \Omega 4$ & $|\mathrm{~b}|$ \\
\hline & & |wa $\mid$ & \rangle$<<$ & $|\mathrm{v}|$ \\
\hline$\sum 1$ & 1 & $|x a||1 a|$ & $K K K$ & $|1|$ \\
\hline$V$ & & $|\mathrm{mi}|$ & $U \varepsilon$ & $|\mathrm{m}|_{1}$ \\
\hline & & $|\mathrm{nu}|$ & 39 & $|\mathrm{n}|$ \\
\hline & & $\mid$ re $\mid$ & $\Lambda$ & $|r|$ \\
\hline & 4 & $|\mathrm{se}|$ & $\psi$ & $|s s|$ \\
\hline & $F$ & $\mid$ ta $\mid$ & 7 & $|t|$ \\
\hline & $\uparrow$ & $|\mathrm{ti}|$ & $\uparrow$ & $|t|_{1}$ \\
\hline
\end{tabular}

\begin{tabular}{|c|c|c|}
\hline \multicolumn{2}{|c|}{ ist of Signs } & \multirow{2}{*}{$\frac{\text { value }}{|a|}$} \\
\hline 1 & $s^{*}$ & \\
\hline 2 & $\sum \Omega 4$ & $|b|$ \\
\hline 3 & $x$ & |e \\
\hline 4 & \rangle$<x$ & $|\mathrm{v}|$ \\
\hline 5 & $\odot 0$ & $\mid$ th $\mid$ \\
\hline 6 & $45 y$ & |il \\
\hline 7 & $B K 14$ & $|1|$ \\
\hline 8 & $<c$ & $|\mathrm{~m}|$ \\
\hline 9 & $U \varepsilon$ & $|\mathrm{m}|_{1}$ \\
\hline 10 & $>>>>$ & $\ln \mid$ \\
\hline 11 & 65 & 10l \\
\hline 12 & $\pi$ & $|\mathrm{p}|$ \\
\hline 13 & $W^{N}{ }^{\prime} N^{*}$ & $|\dot{s}|$ \\
\hline 14 & 9 & \\
\hline 15 & $\Lambda$ & $|r|$ \\
\hline 16 & $P$ & $|r|_{1}$ \\
\hline 17 & $3352^{\circ}$ & $|s|$ \\
\hline 18 & $\psi$ & $|s s|$ \\
\hline 19 & 7 & $|t|$ \\
\hline 20 & $\uparrow$ & $\mathrm{t}_{1}$ \\
\hline & $Y Y V$ & $|u|$ \\
\hline
\end{tabular}

Fig. 2. Signs from the CyproMinoan syllabary (Woudhuizen 1984-5a: 126, Fig. 13).
Fig. 3. List of signs (Woudhuizen 1984-5a: 127, Fig. 14). 


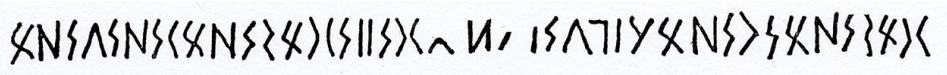

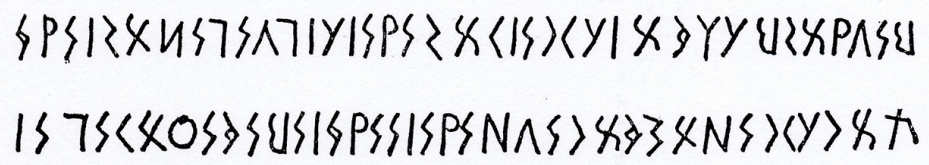

Fig. 4. Inscription S I.2.1 (Nollé 2001: 635).

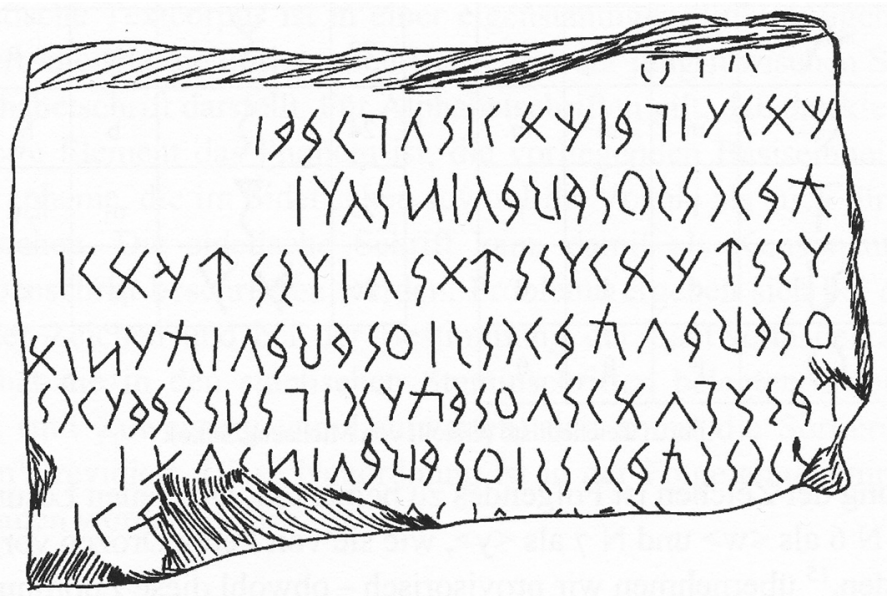

Fig. 5. Inscription S I.2.5 (Zinko 2016: 362, Abb. 3).

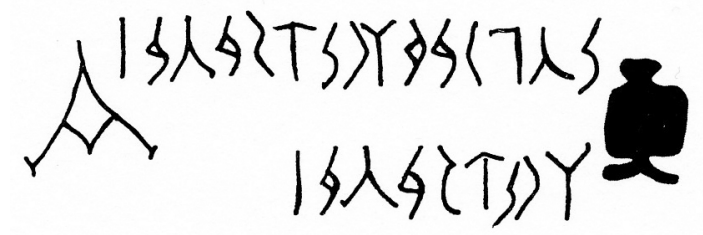

Fig. 6. Inscription S II.1.1 (Nollé 2001: 639). 